\title{
The subsequent newborn effects of stillbirth and abortion, a longitudinal study.
}

Berhanu Elfu Feleke ( $\square$ elfufeleke@gmail.com )

Bahir Dar University https://orcid.org/0000-0001-9251-3337

\section{Teferi Elfu Feleke}

Wolkite University

Research article

Keywords: Newborn effects, abortion, stillbirth, infections

Posted Date: January 24th, 2020

DOI: https://doi.org/10.21203/rs.2.21830/v1

License: (9) This work is licensed under a Creative Commons Attribution 4.0 International License. Read Full License 


\section{Abstract}

Introduction This study was conducted to assess the effects of stillbirth and abortion on the health of the subsequent newborn.

Methods A prospective cohort study was implemented. The data were collected from January 2015 to August 2019. The study participants were selected using the simple random sampling technique. The data were collected using interviewing the pregnant mothers, reviewing medical charts, analyzing the blood samples from the newborn, and scheduled medical checkups. General linear model was used to assess the effects of stillbirth and abortion on the health of the newborn, Poisson regression was used to identify predictors of childhood infectious diseases episodes and Kaplan Meier survival curve were used to estimate time to childhood pneumonia and diarrhea.

Results 2872 infants were included giving for the response rate of $88.97 \%$. Neonate born from mothers with a previous history of stillbirth or abortion had low birth weight, low serum iron, and zinc levels. High infection episodes of diarrhea and pneumonia were observed among infants born from a previous history of stillbirth and abortion mothers. The infection episodes during the childhood period were determined by serum zinc level [IRR $0.71 ; 95 \% \mathrm{Cl}$ : $0.61-0.83$ ], birth weight [IRR $0.86 ; 95 \% \mathrm{Cl}: 0.81-0.91]$, breastfeeding frequency [IRR 0.9; 95\% Cl: 0.87-0.93].

Conclusion The birth weight, serum iron and zinc levels of neonates born from the previous history of stillbirth and abortion were lower. The infection episodes of newborns born from mothers with previous history stillbirth or abortion were higher.

\section{Introduction}

The health of the newborn proximally affected by maternal bad obstetric histories like the previous history of stillbirths and abortion. Each year, 56 million abortion and 2.6 million stillbirths were reported $[1,2]$. The world health organization report indicates that, in 2017, 4.1 million infants' death was recorded mostly from low -income countries [3].

Low birth weight means the birth of the newborn weighing less than $2.5 \mathrm{~kg}$ and affects more than 22.9 million newborns annually [4]. Preterm deliveries, intrauterine growth retardation, multiple pregnancies and disease conditions are some of the reasons for low birth weight delivery [5-7]. The health of low birth weight newborns can be complicated with hypothermia, infections, inadequate feeding, lung immaturity, nervous disorders, necrotizing enterocolitis, and sudden infant death syndrome [8-12].

Micronutrients are vitamins and minerals and they have numerous effects on the health of the newborn. The normal serum iron level for the newborn ranges from 100-250 micrograms/deciliter ( $\mathrm{mcg} / \mathrm{dl})$ [13]. Iron deficiency anemia affects the development of multiple organs during the infancy periods and if not treated early, can cause permanent sequels $[14,15]$. Zinc plays critical roles in fighting against infections 
in the newborn and the normal reference range for the newborn ranges from 0.6-1.2 micrograms per milliliter $(\mathrm{mcg} / \mathrm{ml})[16]$.

Diarrheal diseases and pneumonia are the common infectious diseases observed during the infancy period. Each year, the diarrheal disease affects 1.7 billion children and kills 525000 children [17]. Pneumonia is an inflammation of the lungs and responsible for the death of 808694 children in 2017, that means $15 \%$ of all deaths were attributed by pneumonia [18].

The subsequent pregnancy effects of stillbirth and abortion on the birth weight, serum concentrations of iron, zinc as well as on the episodes of infectious diseases during the infancy were nor clearly known and this study was conducted,

To assess the effects of stillbirth and abortion on the birth weight of subsequent newborn

To estimate the effects of stillbirth and abortion on the newborn serum concentration of zinc and iron To assess the effects of stillbirth and abortion on the episodes of infectious diseases during the infancy period.

\section{Methods And Materials}

A prospective cohort study was implemented among pregnant women with a bad history of obstetric outcomes and a good history of obstetric outcomes in the Mecha demographic surveillance and field research center catchment areas. Pregnant women with a previous history of stillbirth or abortion were labeled as bad obstetric history. The data were collected from January 2015 to August 2019. Pregnant women with bad obstetric history and without bad obstetric history from Mecha demographic surveillance and field research center catchment areas were followed from their pregnancy until 6 months post-partum. The source population of this study was all pregnant mothers. Pregnant mothers with incomplete medical records, unable to give consent, and out migrated from the study areas were excluded from the study. The sample size was calculated using Epi-info software version 7 with the assumption of $95 \% \mathrm{Cl}, 90 \%$ power, previous bad obstetric outcomes to good obstetric outcomes ratio of $1: 2$, a risk ratio of 1.2 and $10 \%$ none response rate. This gives 1076 pregnant mothers with a bad previous history of obstetric outcomes and 2152 pregnant women with no previous history of bad obstetric outcomes. The study participants were selected using the simple random sampling technique. The sampling frame was obtained from Mecha demographic surveillance and field research center database. The data were collected using interviewing the pregnant mothers, reviewing medical charts, analyzing the blood samples from the newborn, and scheduled medical checkups. Baseline data were collected using interview techniques, from each pregnant woman registered from the household registration system database of the research center. Then, update data were collected every week by assigning trained general practitioner from each post-partum mother using their ID numbers from the database of the research center as tracing mechanisms until the infant reach 6 months. Blood samples were obtained from the newborn and analyzed using an atomic absorption spectrophotometer for measuring the serum zinc and the serum iron level was measured using cobas6000 (Roche kits German) instruments (Set 2015; analytics 2014) 
$[19,20]$. Data were entered into the computer using the EPI-info software and transferred to STATA software version 14 for the analysis. Descriptive statistics were used to describe the profile of study participants, general linear model (GLM, multivariate) was used to assess the effects of stillbirth and abortion on the health of the newborn, Poisson regression was used to identify the predictors of childhood infectious diseases episodes and Kaplan Meier survival curves were used to estimate time to childhood pneumonia and diarrhea.

Ethical clearance was obtained from Bahir Dar University's ethical review board. Legal permissions were obtained from the Amhara national regional state health bureau ethical committee and Mecha district health office. Written informed consent was obtained from each study participant. The confidentiality of the data was respected at every step. Study participants the right to withdraw from the study at any point was respected. Infants with pneumonia or diarrhea were linked to the nearby health center curative unit immediately.

\section{Results}

Totally, 2872 infants were included giving for the response rate of $88.97 \% ; 216$ infants were excluded due to incomplete records, 113 study participants were excluded due to outmigration from the study areas, and 27 infants were excluded due to the consents. 15.53\% of infants were from the urban areas. The recurrence rate of stillbirth was $3.67 \%(95 \% \mathrm{Cl}$ : 2.58-5.01) (Table 1). 
Table 1

; Population profile of the study participants $(n=2872)$

\begin{tabular}{|c|c|c|c|c|}
\hline SN & Population profile & & Frequency & Percentage \\
\hline \multirow[t]{3}{*}{1.} & \multirow{3}{*}{$\begin{array}{l}\text { Gestational age during } \\
\text { delivery }\end{array}$} & $\geq 37$ weeks & 549 & 19.12 \\
\hline & & $38-42$ weeks & 2310 & 80.43 \\
\hline & & $>42$ weeks & 13 & 0.45 \\
\hline \multirow[t]{2}{*}{4.} & \multirow[t]{2}{*}{ Residence } & Urban & 446 & 15.53 \\
\hline & & Rural & 2426 & 84.47 \\
\hline \multirow[t]{2}{*}{6.} & \multirow[t]{2}{*}{ Maternal chronic illness } & Present & 454 & 15.81 \\
\hline & & Absent & 2418 & 84.19 \\
\hline \multirow[t]{3}{*}{8.} & \multirow[t]{3}{*}{ Previous pregnancy outcome } & $\begin{array}{l}\text { No history of abortion or } \\
\text { stillbirth }\end{array}$ & 1958 & 68.18 \\
\hline & & Abortion & 37 & 1.29 \\
\hline & & Stillbirth & 877 & 30.54 \\
\hline \multirow[t]{5}{*}{11.} & \multirow[t]{5}{*}{ Gravidity } & 2 & 102 & 3.55 \\
\hline & & 3 & 787 & 27.4 \\
\hline & & 4 & 1462 & 50.91 \\
\hline & & 5 & 509 & 17.72 \\
\hline & & 6 & 12 & 0.42 \\
\hline
\end{tabular}

Table 2

The mean birth weight, serum iron level, and serum zinc levels of neonates born from 3 different groups of mothers $(n=2872)$

\begin{tabular}{|lllllll|}
\hline Groups of mother & \multicolumn{2}{l}{$\begin{array}{l}\text { Birth weight in } \\
\text { kilogram }\end{array}$} & \multicolumn{2}{l|}{$\begin{array}{l}\text { Serum zinc level in } \\
\mathrm{mcg} / \mathrm{ml}\end{array}$} & \multicolumn{2}{l|}{$\begin{array}{l}\text { Serum iron level in } \\
\mathrm{mcg} / \mathrm{dl}\end{array}$} \\
\cline { 2 - 6 } & Mean & SD & Mean & SD & Mean & SD \\
\hline $\begin{array}{l}\text { No history of stillbirth or } \\
\text { abortion }\end{array}$ & 2.72 & 0.48 & 0.83 & 0.1 & 157.53 & 29.62 \\
\hline History of abortion & 2.5 & $<0.01$ & 0.7 & $<0.01$ & 92.43 & 16.73 \\
\hline History of stillbirth & 1.97 & 0.37 & 0.59 & 0.2 & 97.86 & 24.26 \\
\hline
\end{tabular}


Neonate born from mothers with a previous history of abortion had significantly lower birth weight, serum zinc level, and serum iron level as compared to neonates born from mothers with no previous history of stillbirth or abortion (Table 2).

After adjusting for maternal chronic illnesses, maternal age, parity, gestational age, ante-partum hemorrhage, residence, previous history of stillbirth or abortion: the neonatal birth weight, serum iron level, and the serum zinc levels were determined by; previous history of abortion, previous history of stillbirth, gestational age during delivery, residence, maternal chronic illnesses, and maternal age (Table 3). 
Table 3

Multivariate analysis for the determinants of birth weight, serum iron levels and serum zinc levels $(n=$ 2872).

\begin{tabular}{|c|c|c|c|c|c|}
\hline \multirow{2}{*}{$\begin{array}{l}\text { Dependent } \\
\text { variable }\end{array}$} & \multirow[t]{2}{*}{ Predictors } & \multirow[t]{2}{*}{$\beta$} & \multicolumn{2}{|c|}{$95 \% \mathrm{Cl}$ for $\beta$} & \multirow{2}{*}{$\begin{array}{l}\mathrm{p}- \\
\text { value }\end{array}$} \\
\hline & & & $\begin{array}{l}\text { Lower } \\
\text { Bound }\end{array}$ & $\begin{array}{l}\text { Upper } \\
\text { Bound }\end{array}$ & \\
\hline \multirow[t]{7}{*}{$\begin{array}{l}\text { Iron level in } \\
\mathrm{mcg} / \mathrm{dl}\end{array}$} & Maternal chronic illnesses & -5.85 & -8.64 & -3.06 & $\begin{array}{l}< \\
0.01\end{array}$ \\
\hline & Residence & 5.71 & 2.36 & 9.07 & $\begin{array}{l}<.01 \\
0.01\end{array}$ \\
\hline & Gestational age during delivery & 3.20 & 2.61 & 3.79 & $\dot{0.01}$ \\
\hline & Maternal age & -0.41 & -0.68 & -0.14 & $\begin{array}{l}<.01 \\
0.01\end{array}$ \\
\hline & $\begin{array}{l}\text { No previous history of abortion or } \\
\text { stillbirth }\end{array}$ & 65.98 & 56.46 & 75.49 & $\begin{array}{l}<.01 \\
0.01\end{array}$ \\
\hline & Maternal history of abortion & 38.93 & -57.95 & 135.82 & 0.43 \\
\hline & Maternal history of stillbirth & \multicolumn{4}{|c|}{ Reference category } \\
\hline \multirow[t]{5}{*}{$\begin{array}{l}\text { Zinc level in } \\
\mathrm{mcg} / \mathrm{ml}\end{array}$} & Ante-partum hemorrhage & -0.04 & -0.02 & -0.06 & $\begin{array}{l}<.01 \\
0.01\end{array}$ \\
\hline & Gestational age during delivery & 0.01 & 0.01 & 0.02 & $\begin{array}{l}< \\
0.01\end{array}$ \\
\hline & $\begin{array}{l}\text { No previous history of abortion or } \\
\text { stillbirth }\end{array}$ & 0.22 & 0.17 & 0.27 & $\begin{array}{l}<.01 \\
0.01\end{array}$ \\
\hline & Maternal history of abortion & 0.09 & -0.41 & 0.59 & 0.72 \\
\hline & Maternal history of stillbirth & \multicolumn{4}{|c|}{ Reference category } \\
\hline \multirow[t]{6}{*}{ Birth weight } & Ante-partum hemorrhage & -0.23 & -0.17 & -0.29 & $\begin{array}{l}<.01 \\
0.01\end{array}$ \\
\hline & Residence & -0.20 & -0.25 & -0.14 & $\dot{0} 01$ \\
\hline & Gestational age during delivery & 0.06 & 0.05 & 0.07 & $\begin{array}{l}<.01 \\
0.01\end{array}$ \\
\hline & Maternal age & 0.01 & 0.00 & 0.01 & $\begin{array}{l}<.01 \\
0.01\end{array}$ \\
\hline & $\begin{array}{l}\text { No previous history of abortion or } \\
\text { stillbirth }\end{array}$ & 0.63 & 0.48 & 0.78 & $\begin{array}{l}<.01 \\
0.01\end{array}$ \\
\hline & Maternal history of abortion & 0.30 & -1.21 & 1.81 & 0.70 \\
\hline
\end{tabular}


During the subsequent 6 months of life, $73 \%$ of infants born from mothers with a previous history of abortion had 4 episodes of infectious diseases, and $71 \%$ of infants born from mothers with previous history of stillbirth had 4 episodes of infectious diseases in the subsequent 6 months of life. After adjusting for gestational weeks during delivery, birth weight, serum iron and serum zinc level during delivery, breastfeeding, immunization for age, maternal history of stillbirth or abortion, residence, maternal chronic illnesses: the episodes of childhood infection were determined by maternal history of abortion or stillbirth, birth weight, breastfeeding, the serum zinc and iron level during the delivery (Table 4).

Table 4

Poisson regression outputs for the determinants of childhood infectious diseases $(n=$ 2872).

\begin{tabular}{|llllll|}
\hline Predictors & $\boldsymbol{\beta}$ & Sig. & IRR & \multicolumn{2}{c|}{ 95\% IRR } \\
\cline { 5 - 7 } & & & & Lower & Upper \\
\hline No previous history of abortion or stillbirth & -0.14 & $<0.01$ & 0.87 & 0.80 & 0.95 \\
\hline Maternal history of abortion & 0.19 & 0.04 & 1.21 & 1.01 & 1.45 \\
\hline Maternal history of stillbirth & \multicolumn{2}{l}{ Reference category } & & \\
\hline Serum iron level during delivery & 0.00 & $<0.01$ & 1.00 & 1.00 & 1.00 \\
\hline Serum zinc level during delivery & -0.34 & $<0.01$ & 0.71 & 0.61 & 0.83 \\
\hline Birth weight & -0.16 & $<0.01$ & 0.86 & 0.81 & 0.91 \\
\hline Breastfeeding & -0.10 & $<0.01$ & 0.90 & 0.87 & 0.93 \\
\hline
\end{tabular}

Pneumonia and diarrhea were the most common complications of childhood infections occurred as a result of stillbirth and abortion. Among infants born from mothers with a previous history of abortion, $100 \%$ of the infants were attacked by diarrhea and $29 \%$ of them suffer from pneumonia in the subsequent 6 months. 94.3\% of infants born from mothers with a previous history of stillbirth develop diarrhea in the subsequent 6 months. The median time of diarrhea among infants born from a previous history of abortion was 3 weeks and among infants born from previous history of stillbirth was 5 weeks. The median time diarrhea among infants born from mothers with no previous history of abortion or stillbirth was 15 weeks (Fig. 1 and Fig. 2).

\section{Discussion}

The serum iron levels of a neonate born from mothers with chronic illnesses were $5.85 \mathrm{mcg} / \mathrm{dl}$ lower than neonate born from mothers free from chronic illnesses. This finding agrees with research outputs from 
Mexico [21]. This is due to the effects of maternal chronic diseases on fetal perfusions which finally decreases the amount of iron transferred from the mother to the fetus [22].

The serum iron levels of neonates born from urban mothers were $5.71 \mathrm{mcg} / \mathrm{dl}$ higher than the rural mothers. This is due to the reasons that low maternal and health service utilization of pregnant mothers in the rural areas which significantly decreases the iron concentration of the neonates [23].

Per a year increase in the age of the mother, the serum iron level of the neonate decreases by 0.41 $\mathrm{mcg} / \mathrm{dl}$. This finding agrees with finding from Israel [24]. This is due to the negative effects of old age pregnancy on the fetal hematopoiesis [25].

The serum iron levels of a neonate born from mothers with no history of stillbirth were $65.98 \mathrm{mcg} / \mathrm{dl}$ higher than neonates born from mothers with a history of stillbirth. This is due to the effects of stillbirth on the iron store of the mothers that affects the concentration for the infants [26].

Ante-partum hemorrhage decreases the serum zinc level of the neonate by $0.04 \mathrm{mcg} / \mathrm{ml}$. This is the direct association between maternal zinc deficiency and low fetal zinc levels because Antepartum hemorrhage depletes the zinc concentration of the mothers $[27,28]$.

The serum zinc level of a neonate increase by $0.01 \mathrm{mcg} / \mathrm{ml}$ per one year increase in the gestational age. This finding was in line with the research results from China [29]. This is due to the reason that adequate amount of zinc will not be transferred during preterm delivery [30].

The serum zinc level of a neonate born from mothers with a history of stillbirth was $0.22 \mathrm{mcg} / \mathrm{ml}$ lower than neonate born from mothers with no history of stillbirth. This is due to the effects of stillbirth on the serum micronutrient levels of the mothers which finally decreases the transfer of zinc to the subsequent fetus [31].

Antepartum hemorrhage decreases the birth weight of a neonate by 0.23 kilogram. This finding agrees with finding from Pakistan [32]. This is due to the reason that bleeding during pregnancy decreases the transfer of the essential nutrient to the fetus [33].

The birth weight of a neonate born from urban mothers was $0.2 \mathrm{~kg}$ less than the rural residence. This finding agrees with findings from South Sudan [34]. This is due to the good social support of pregnant women during pregnancy in the rural areas [35].

A one-week increase in the gestational age increases the birth weight of a neonate by $0.06 \mathrm{~kg}$. This finding agrees with USA finding [36]. This is due to the fact that preterm births did not get enough quantity of nutrients necessary to achieve the normal birth weight [37].

The birth weight increase by $0.01 \mathrm{~kg}$ per one year increase in the age of the mother. This finding disagree with a 2016 fining [38]. This is due to the reason that the awareness of mothers will be increased as their 
age increases due to the repeated exposure which finally makes them to take enough quantity and quality of nutrient necessary for their fetus growth [6].

The birth weight of a neonate born from mothers with no history of stillbirth was $0.63 \mathrm{~kg}$ higher than neonate born from mother with a history of stillbirth. This finding agrees with research output from USA [39]. This is due to the high gravidity effects on the birth weight of the neonates, like the mother became anemic which decreases the fetal nutrition supply [40].

Infectious disease episodes were $14 \%$ lower for infants born from no history of stillbirth mothers as compared to infants born from mothers with a history of stillbirth. This is due to the effects of stillbirth on the immunity of subsequent infants [41].

An infant born from mothers with a history of abortion had $14 \%$ higher infection rate as compared to infants born from mothers with no history of abortion. Diarrheal diseases and pneumonia were the common infectious diseases observed among infants born from previous history of abortion. This is due to the effects of abortion on the immune status of the mother which makes poor transfer of passive immunity from the mother to the fetus [42].

Infectious disease episode decreases by $14 \%$ per one kilogram increase in the birth weight of the newborn. This finding agrees with findings from Benin [43]. This is due to reason that low birth weight has poor cellular and humoral immunity to protect themselves from the infections[44].

One unit increase in the breastfeeding frequency decreases the infectious disease episode by $10 \%$. This finding was in line with previous research results [45-47]. This is due to the fact that breast milk is one form of immunity with no side effects and infants with complementary feedings had high rate of gastrointestinal and respiratory infections [48-50].

The main limitation of this study was failure to identify the long-term effects of stillbirth and abortion to the subsequent children.

\section{Conclusion}

Stillbirth and abortion significantly decreases the subsequent newborn weight, serum zinc level and serum iron level. Both abortion and stillbirths increase the number of infectious disease episodes to the subsequent newborn. The birth weight, breastfeeding frequency and the serum zinc levels determines the number of infectious disease episodes during the infancy periods. Diarrheal diseases and pneumonia were the most frequent complications of subsequent infants born from mothers with a history of abortion or stillbirth.

\section{Abbreviations}

B; Beta-coefficient 
BDU; Bahir Dar University

$\mathrm{C} / \mathrm{S}$; Cesarean section

$\mathrm{Cl}$; Confidence interval

G/dl; Gram per deciliter

GEE; Generalized estimating equation

Ml; Milliliter

SD; Standard deviation

SN; Serial number

USA; United State of America

\section{Declarations}

\section{Ethics approval and consent to participate}

Ethical clearance was obtained from Bahir Dar University's ethical review board. Legal permissions were obtained from the Amhara national regional state health bureau ethical committee and Mecha district health office. Written informed consent was obtained from each study participant. The confidentiality of the data was respected at every step. Study participants the right to withdraw from the study at any point was respected. Infants with pneumonia or diarrhea were linked to the nearby health center curative unit immediately.

\section{Consent for publication}

Not applicable

\section{Availability of Data and Materials}

The datasets used and/or analyzed during the current study are available from the corresponding author on reasonable request.

\section{Competing interests}

The authors declares that they have no competing interests

\section{Funding}


This research work was financially supported by federal democratic republic of Ethiopia ministry of health and Bahir Dar University. The funder has no role in design of the study and collection, analysis, and interpretation of data and in writing the manuscript.

\section{Author contribution}

BEF conceived the experiment; BEF and TEF performed the experiment, plan the data collection process, analyzed and interpreted the data. BEF and TEF wrote the manuscript and approved the final draft for publication.

\section{Acknowledgements}

We would like to acknowledge the Amhara national, regional health officers for their unreserved efforts during the fieldwork. Our thanks also extended to Mecha district health offices for their positive support during the data collection stage. At last but not least, we would like to acknowledge all organizations and individuals that contributed to this work.

\section{References}

1. Lawn JE, Lee AC, Kinney M, Sibley L, Carlo WA, Paul VK, Pattinson R, Darmstadt GL: Two million intrapartum-related stillbirths and neonatal deaths: where, why, and what can be done? International journal of gynaecology and obstetrics: the official organ of the International Federation of Gynaecology and Obstetrics 2009, 107 Suppl 1:S5-18, s19.

2. Ganatra B, Gerdts C, Rossier C, Johnson Jr BR, Tunçalp Ö, Assifi A, Sedgh G, Singh S, Bankole A, Popinchalk A: Global, regional, and subregional classification of abortions by safety, 2010-14: estimates from a Bayesian hierarchical model. The Lancet 2017, 390(10110):2372-2381.

3. Organization WH: Global Diffusion of EHealth: Making Universal Health Coverage Achievable: Report of the Third Global Survey on EHealth: World Health Organization; 2017.

4. Organization WH: UNICEF-WHO low birthweight estimates: levels and trends 2000-2015. In.: United Nations Children's Fund ( UNICEF); 2019.

5. Mahumud RA, Sultana M, Sarker AR: Distribution and determinants of low birth weight in developing countries. Journal of preventive medicine and public health 2017, 50(1):18.

6. Demelash H, Motbainor A, Nigatu D, Gashaw K, Melese A: Risk factors for low birth weight in Bale zone hospitals, South-East Ethiopia: a case-control study. BMC pregnancy and childbirth 2015, 15(1):264.

7. Griffin IJ, Tancredi DJ, Bertino E, Lee HC, Profit J: Postnatal growth failure in very low birthweight infants born between 2005 and 2012. Archives of Disease in Childhood-Fetal and Neonatal Edition 2016, 101(1):50-55. 
8. Wallenstein MB, Birnie KL, Arain YH, Yang W, Yamada NK, Huffman LC, Palma JP, Chock VY, Shaw GM, Stevenson DK: Failed endotracheal intubation and adverse outcomes among extremely low birth weight infants. Journal of Perinatology 2016, 36(2):112.

9. Hakeem GF, Oddy L, Holcroft CA, Abenhaim HA: Incidence and determinants of sudden infant death syndrome: a population-based study on 37 million births. World Journal of Pediatrics 2015, 11(1):4147.

10. Chang H-Y, Sung Y-H, Wang S-M, Lung H-L, Chang J-H, Hsu C-H, Jim W-T, Lee C-H, Hung H-F: Shortand long-term outcomes in very low birth weight infants with admission hypothermia. PloS one 2015, 10(7): $\mathrm{e} 0131976$.

11. Moreira D, Melton K, Meinzen-Derr J, Tabangin M, Kingma P, Schibler K: Heart Rate Characteristic Index Monitoring for Early Detection of Infections in Very Low Birth Weight Infants. American Journal of Pediatrics 2019, 5(3):170-174.

12. Stefanescu BM, Gillam-Krakauer M, Stefanescu AR, Markham M, Kosinski JL: Very low birth weight infant care: adherence to a new nutrition protocol improves growth outcomes and reduces infectious risk. Early human development 2016, 94:25-30.

13. Christensen R, Henry E, Bennett S, Yaish H: Reference intervals for reticulocyte parameters of infants during their first 90 days after birth. Journal of Perinatology 2016, 36(1):61.

14. Beard J: Iron deficiency alters brain development and functioning. The Journal of nutrition 2003 , 133(5):1468S-1472S.

15. Beard JL: Why iron deficiency is important in infant development. The Journal of nutrition 2008, 138(12):2534-2536.

16. Krachler M, Rossipal E, Micetic-Turk D: Concentrations of trace elements in sera of newborns, young infants, and adults. Biological trace element research 1999, 68(2):121.

17. WHO: Diarrhoeal disease. In., vol. 1. Geneva, Swetherland: World health organization; 2017.

18. WHO: Pneumonia. In., vol. 1. Geneva, Swetherland: World Health Organization; 2019.

19. Smith J, Butrimovitz G, Purdy W: Direct measurement of zinc in plasma by atomic absorption spectroscopy. Clinical Chemistry 1979, 25(8):1487-1491.

20. Lewis S, Hardison N, Veillon C: Comparison of isotope dilution mass spectrometry and graphite furnace atomic absorption spectrometry with Zeeman background correction for the determination of plasma selenium. Analytical chemistry 1986, 58(6):1272-1273.

21. Meinzen-Derr JK, Guerrero ML, Altaye M, Ortega-Gallegos H, Ruiz-Palacios GM, Morrow AL: Risk of Infant Anemia Is Associated with Exclusive Breast-Feeding and Maternal Anemia in a Mexican Cohort. The Journal of Nutrition 2006, 136(2):452-458.

22. Cetin I, Mandò C, Parisi F: Maternal Characteristics Predisposing to Fetal Growth Restriction. In: Diet, Nutrition, and Fetal Programming. edn.: Springer; 2017: 55-66.

23. Ahmed F, Khan MR, Chowdhury IA, Raqib R, Roy AK, Chowdhury R: Effect of routine iron-folic acid supplementation among rural pregnant women living in low-and high-groundwater-iron areas in 
Bangladesh. Public health nutrition 2019, 22(15):2844-2855.

24. Schimmel MS, Bromiker R, Hammerman C, Chertman L, loscovich A, Granovsky-Grisaru S, Samueloff A, Elstein D: The effects of maternal age and parity on maternal and neonatal outcome. Archives of gynecology and obstetrics 2015, 291(4):793-798.

25. Kamimae-Lanning AN, Krasnow SM, Goloviznina NA, Zhu X, Roth-Carter QR, Levasseur PR, Jeng S, McWeeney SK, Kurre P, Marks DL: Maternal high-fat diet and obesity compromise fetal hematopoiesis. Molecular metabolism 2015, 4(1):25-38.

26. Tomashek KM, Ananth CV, Cogswell ME: Risk of stillbirth in relation to maternal haemoglobin concentration during pregnancy. Maternal \& child nutrition 2006, 2(1):19-28.

27. Bassiouni BA, Foda Al, Rafei AA: Maternal and fetal plasma zinc in preeclampsia. European Journal of Obstetrics \& Gynecology 1979, 9(2):75-80.

28. Ota E, Mori R, Middleton P, Tobe-Gai R, Mahomed K, Miyazaki C, Bhutta ZA: Zinc supplementation for improving pregnancy and infant outcome. Cochrane Database of Systematic Reviews 2015(2).

29. Xiang H, Liang C, Yan S, Li Z, Li J, Huang K, Tao R, Zhang Q, Hao J, Tao F: The relationship of maternal and umbilical cord blood zinc level associated with newborn birth weight: a birth cohort study. Zhonghua yu fang yi xue za zhi [Chinese journal of preventive medicine] 2018, 52(10):10081012.

30. Ofakunrin A, Collins J, Diala U, Afolaranmi T, Okolo S: Relationship between maternal serum zinc, cord blood zinc and birth weight of term newborn infants in Jos, Plateau State, Nigeria. Jos Journal of Medicine 2017, 11(2):12-20.

31. Wang H, Hu Y-F, Hao J-H, Chen Y-H, Su P-Y, Wang Y, Yu Z, Fu L, Xu Y-Y, Zhang C et al: Maternal zinc deficiency during pregnancy elevates the risks of fetal growth restriction: a population-based birth cohort study. Scientific Reports 2015, 5:11262.

32. Mushtaq R, Abbas $A$, Ahmed W: Perinatal outcomes in pregnant patients presenting with antepartum hemorrhage: Our experiences at a teaching hospital in Central Punjab. The Professional Medical Journal 2019, 26(10):1645-1650.

33. Dynin M, Lane DR: Bleeding in Late Pregnancy. In: Emergency Department Management of Obstetric Complications. edn.: Springer; 2017: 53-62.

34. Alumai J: Prevalence And Associated Risk Factors For Low Birth Weight In Bentiu State Hospital, Unity State, South Sudan. CIU; 2018.

35. Muhwava LS, Morojele N, London L: Psychosocial factors associated with early initiation and frequency of antenatal care (ANC) visits in a rural and urban setting in South Africa: a crosssectional survey. BMC pregnancy and childbirth 2016, 16(1):18.

36. Frey HA, Klebanoff MA: The epidemiology, etiology, and costs of preterm birth. Seminars in Fetal and Neonatal Medicine 2016, 21(2):68-73.

37. Zerfu TA, Pinto E, Baye K: Consumption of dairy, fruits and dark green leafy vegetables is associated with lower risk of adverse pregnancy outcomes (APO): a prospective cohort study in rural Ethiopia. Nutrition \& diabetes 2018, 8(1):52. 
38. Zheng W, Suzuki K, Tanaka T, Kohama M, Yamagata Z, The Okinawa Child Health Study G: Association between Maternal Smoking during Pregnancy and Low Birthweight: Effects by Maternal Age. PLOS ONE 2016, 11(1):e0146241.

39. Batra $P$, Higgins $C$, Chao SM: Previous adverse infant outcomes as predictors of preconception care use: an analysis of the 2010 and 2012 Los Angeles mommy and baby (LAMB) surveys. Maternal and child health journal 2016, 20(6):1170-1177.

40. Feleke BE, Feleke TE: Pregnant mothers are more anemic than lactating mothers, a comparative cross-sectional study, Bahir Dar, Ethiopia. BMC hematology 2018, 18(1):2.

41. Robichaud MV, Pearl D, Godden S, LeBlanc S, Haley D: Systematic early obstetrical assistance at calving: I. Effects on dairy calf stillbirth, vigor, and passive immunity transfer. Journal of dairy science 2017, 100(1):691-702.

42. Daglar K, Biberoglu E, Kirbas A, Dirican AO, Genc M, Avci A, Biberoglu K: The cellular immunity and oxidative stress markers in early pregnancy loss. The Journal of Maternal-Fetal \& Neonatal Medicine 2016, 29(11):1840-1843.

43. Cottrell G, Moussiliou A, Luty AJ, Cot M, Fievet N, Massougbodji A, Deloron P, Tuikue Ndam N: Submicroscopic Plasmodium falciparum infections are associated with maternal anemia, premature births, and low birth weight. Clinical Infectious Diseases 2015, 60(10):1481-1488.

44. Collado MC, Cernada M, Neu J, Pérez-Martínez G, Gormaz M, Vento M: Factors influencing gastrointestinal tract and microbiota immune interaction in preterm infants. Pediatric research 2015, 77(6):726.

45. Quigley MA, Carson C, Sacker A, Kelly Y: Exclusive breastfeeding duration and infant infection. European Journal of Clinical Nutrition 2016, 70(12):1420-1427.

46. Netzer-Tomkins H, Rubin L, Ephros M: Breastfeeding Is Associated with Decreased Hospitalization for Neonatal Fever. Breastfeeding Medicine 2016, 11(5):218-221.

47. Zivich P, Lapika B, Behets F, Yotebieng M: Implementation of Steps 1-9 to Successful Breastfeeding Reduces the Frequency of Mild and Severe Episodes of Diarrhea and Respiratory Tract Infection Among 0-6 Month Infants in Democratic Republic of Congo. Maternal and Child Health Journal 2018, 22(5):762-771.

48. Ajetunmobi OM, Whyte B, Chalmers J, Tappin DM, Wolfson L, Fleming M, MacDonald A, Wood R, Stockton DL: Breastfeeding is associated with reduced childhood hospitalization: evidence from a Scottish Birth Cohort (1997-2009). The Journal of pediatrics 2015, 166(3):620-625. e624.

49. O'Sullivan A, Farver M, Smilowitz JT: Article commentary: the influence of early infant-feeding practices on the intestinal microbiome and body composition in infants. Nutrition and metabolic insights 2015, 8:NMI. S29530.

50. Payne S, Quigley MA: Breastfeeding and infant hospitalisation: analysis of the UK 2010 Infant Feeding Survey. Maternal \& child nutrition 2017, 13(1):e12263.

\section{Supplementary Files}


This is a list of supplementary files associated with this preprint. Click to download.

- S2fileSTROBEchecklistcohort.docx

- S2Fig2.tif

- S1Fig1.tif 